\title{
Promoting resilience for teachers: pre-service and in-service professional learning
}

\author{
Caroline Mansfield $^{1}$ (D) Susan Beltman ${ }^{2}$ (D)
}

Received: 29 July 2019 / Accepted: 5 August 2019 / Published online: 19 August 2019

(C) The Australian Association for Research in Education, Inc. 2019

This Special Issue brings together international research focusing on promoting resilience for teachers through professional learning experiences. The collection includes papers presenting empirical research with pre-service teachers and in-service teachers, in a range of contexts and countries, using traditional and innovative methodologies, and examining both formal and informal professional learning experiences. Given widespread professional concerns such as teacher stress and attrition (Harmsen et al. 2018; Kelchtermans 2017), teacher well-being (Fleming et al. 2013; Schleicher 2018), and quality teacher retention (Day and Gu 2014), this Special Issue offers a unique contribution to the field by illustrating the ways in which teacher resilience can be promoted through professional learning experiences.

Teacher resilience research has flourished over the past 15 years and studies have shown resilience related to numerous positive outcomes for teachers including job satisfaction, commitment, efficacy, engagement, motivation, well-being and positive sense of identity (see for example, Day and Gu 2014; Day and Hong 2016; Hong 2012; Mansfield et al. 2016a; Papatraianou and Le Cornu 2014). Recently, resilience has been acknowledged as a critical non-cognitive attribute of novice teachers (Klassen et al. 2018) and in countries such as Australia there has been heightened interest, as resilience has been considered an important non-cognitive capability for selecting applicants into teacher education (Australian Institute of Teaching and School Leadership [AITSL] 2015).

Many studies in the field have explored resilience by investigating perspectives of teachers at various career stages (for example, Day et al. 2006), focusing on the relational world of teaching and its influence on resilience (for example, Le Cornu 2013), and exploring the micro and macro ecologies that impact on teacher resilience in different countries and contexts (for example, Mansfield et al. 2018). While

Caroline Mansfield

caroline.mansfield1@nd.edu.au

Susan Beltman

S.Beltman@curtin.edu.au

1 The University of Notre Dame Australia, PO Box 1225, Fremantle 6959, Australia

2 Curtin University, GPO Box U1987, Perth, WA 6845, Australia 
the extant literature has enabled comprehensive understandings of teacher resilience and how it may be challenged and supported through personal and contextual risks and resources, the issue of how teacher resilience may be promoted through professional learning has received less emphasis. Recent research provides emerging evidence that resilience related skills and strategies can be enhanced during pre-service teacher education (for example, Beltman et al. 2018; Peixoto et al. 2018) and there is also some support for the view that professional learning opportunities for in-service teachers may also play a role in supporting teacher resilience throughout the career span (for example, Gibbs and Miller 2013). A focus on professional learning experiences that promote resilience is the next step in the field as recently highlighted by Wosnitza et al. (2018).

The papers in this Special Issue share a social ecological view of resilience (Ungar 2012) and the view of resilience as the capacity of an individual teacher to harness personal and contextual resources to navigate through challenges, as well as the dynamic process whereby characteristics of individual teachers and of their personal and professional contexts interact over time as teachers use particular strategies, to enable the outcome of a teacher who experiences professional engagement and growth, commitment, enthusiasm, satisfaction, and well-being (Beltman 2015; Mansfield et al. 2016b). A social ecological view of resilience enables resilience resources at various system levels to be examined and takes into account the role of and interaction between both person and context factors. This view aligns with Masten's (2014) description of the resilience process as involving "many systems within the individual as well as many systems outside the individual" (p. 170) and whereby "adaptive function of the individual is interdependent with many other systems at different levels of function that are continually interacting" (p. 170). The papers in this Special Issue focus on various systems to address the aims of the study and interpret findings.

The research setting of the first three papers is that of Australian pre-service teacher education. The first paper, by McGraw and McDonough, uses a thinking dispositions framework and extends beyond the personal system to examine pre-service teachers' experiences as they move into their first structured professional experience placement in schools. An Australian University-School partnership is described, along with the strategies to support the pre-service teachers' professional learning. Developing good relationships with students and colleagues was found to be a critical resource for resilience.

The second paper by Beutel and colleagues, in the context of an Australian formal pre-service teacher education professional course, explores personal and contextual resources available to pre-service teachers to support their resilience during a professional learning placement. Focus groups and prepared case studies were used to generate data. The support of others, this time supervising teachers, family and friends, as well as the wider school context were again crucial in this high stakes setting where a range of strategies and resources are needed for success.

The third paper by Weatherby-Fell and colleagues is also set in the context of a formal Australian pre-service course, this time with pre-service teachers in an early childhood course. Also centred on the high stakes setting of a professional experience placement, this study uses interviews to examine the role of an online 
professional learning tool designed to build capacity for resilience in pre-service teachers (BRiTE). Participants spoke about their anticipated and experienced challenges as well as the resources used. Again, relationships with others in the context were important, such as colleagues in the early learning centre and university supervising staff. Relationships with the pupils' families were also important in this setting. The authors note that having the BRiTE modules integrated into their wider course contributed to their positive impact.

In the fourth paper of this Special Issue, Mansfield and Gu examine the support provided to Australian early career teachers as they move beyond the university into the workplace. Two online surveys at different time points and telephone interviews were used to examine the nature and impact of beginning teachers' formal and informal professional learning activities. The authors describe a wide range of activities that were undertaken along a continuum of informal to formal activities and suggest that a simple informal-formal dichotomy is unhelpful. The findings highlight the importance of multiple levels of context, as beginning teachers observed and were observed by more experienced colleagues, took part in formal programs, read relevant literature, and participated in wider professional networks. Having the support of an in-class personal coach was found to be particularly beneficial, emphasising again the importance of trusting relationships.

The fifth paper by Beltman and Poulton focuses on the personal system and more experienced teachers. Data for the study were extracted from an innovative online professional learning tool designed for promoting pre-service teacher resilience but used by a wide range of educators (BRiTE). The paper examines the strategies reported by in-service teachers from several countries who completed the online modules and responded to a question regarding the strategies for managing heightened emotions. The strategies are discussed in terms of constructs such as emotional regulation and coping, as well as resilience. Consistent with some other papers in this Special Issue, teacher responses focused on strategies within the personal system and immediate context, raising the issue of how to encourage and enhance the role of wider systems in supporting teacher resilience.

Paper six, by Fernandes and colleagues from Portugal, presents a quasi-experimental, quantitative study regarding the effects of a professional learning program for in-service teachers. Using a multidimensional, multi-level approach, the authors measured personal level constructs such as commitment, self-efficacy and motivation, as well as wider level contextual aspects such as perceived school support. In partnership with schools, the university developed and conducted a face-to-face professional learning program comprising a number of modules. The authors discuss some promising as well as contradictory findings, indicating ways that the modules could be used to enhance and support teacher resilience.

The final, seventh paper by Collie and Perry is a conceptual paper which presents a model of resilience centred on teachers' social-emotional competence: the Framework for Cultivating Teacher Thriving. Included in the model is the construct of relatedness and the important role of school leaders who are caring and provide emotional support to teachers is outlined. The role of professional learning in developing skills and therefore perceived competence and autonomy is also discussed. In addition, the classroom, school and system contexts are explicitly included in the 
framework, as well as the interrelationships between all its elements. The authors suggest that teachers' thriving or resilience is best promoted by a combination of organisation-led and teacher-initiated efforts for developing social-emotional competence.

This Special Issue is innovative in nature, bringing together empirical and conceptual studies focused on the same theme, yet moving the field forward to focus on the role of formal and informal professional learning in the teacher resilience process. Methodologically, the collection of studies draws on qualitative, quantitative and mixed methods approaches. The Special Issue is of interest to teacher educators, pre-service and in-service teachers, education sectors, psychologists, researchers investigating professional resilience in other disciplines (e.g., nursing, veterinary medicine, social work) as well as those interested in the potential of interventions to support resilience. Future research directions and practical implications are raised in and arise from the Special Issue papers. For example, can we develop observational measures of teacher resilience, to complement survey and interview data, to determine the impact of interventions rather than relying on self-reports? How can systems offer a range of formal and informal professional learning that is still personalised and how can individuals, universities, schools and systems work together to provide this comprehensive range? Given the multidimensional nature of resilience and the dynamic complexity of multiple contexts, are there some key elements of content or format that should be featured in professional learning interventions? It is well established that professional resilience is linked with personal well-being, professional longevity, workplace collegiality, and supportive workplaces and policies. This Special Issue addresses the next step by illustrating ways to promote professional resilience through professional learning.

\section{References}

Australian Institute for Teaching and School Leadership [AITSL]. (2015). Action now: Selection of entrants into initial teacher education. Melbourne: AITSL. Retrieved from http://www.aitsl.edu. au/initial-teacher-education/ite-reform/selection.

Beltman, S. (2015). Teacher professional resilience: Thriving not just surviving. In N. Weatherby-Fell (Ed.), Learning to teach in the secondary school (pp. 20-38). Melbourne: Cambridge University Press.

Beltman, S., Mansfield, C. F., Wosnitza, M., Weatherby-Fell, N., \& Broadley, T. (2018). Using online modules to build capacity for teacher resilience. In M. Wosnitza, F. Peixoto, S. Beltman, \& C. F. Mansfield (Eds.), Resilience in education: Concepts, contexts and connections (pp. 237-253). Cham: Springer International Publishing.

Day, C., \& Gu, Q. (2014). Resilient teachers, resilient schools: Building and sustaining quality in testing times. Oxon: Routledge.

Day, C., \& Hong, J. (2016). Influences on the capacities for emotional resilience of teachers in schools serving disadvantaged urban communities: Challenges of living on the edge. Teaching and Teacher Education, 59, 115-125. https://doi.org/10.1016/j.tate.2016.05.015.

Day, C., Sammons, P., Kington, A., Gu, Q., \& Stobart, G. (2006). Methodological synergy in a national project: The VITAE story. Evaluation and Research in Education, 19(2), 102-125. https ://doi.org/10.2167/eri422.0. 
Fleming, J. L., Mackrain, M., \& LeBuffe, P. A. (2013). Caring for the caregiver: Promoting the resilience of teachers. In S. Goldstein \& R. B. Brooks (Eds.), Handbook of resilience in children. New York: Springer Science + Business Media.

Gibbs, S., \& Miller, A. (2013). Teachers' resilience and well-being: A role for educational psychology. Teachers and Teaching: Theory and Practice, 20(5), 609-621. https://doi.org/10.1080/13540 602.2013.844408.

Harmsen, R., Helms-Lorenz, M., Maulana, R., \& van Veen, K. (2018). The relationship between beginning teachers' stress causes, stress responses, teaching behaviour and attrition. Teachers and Teaching. https://doi.org/10.1080/13540602.2018.1465404.

Hong, J. Y. (2012). Why do some beginning teachers leave the school, and others stay? Understanding teacher resilience through psychological lenses. Teachers and Teaching: Theory and Practice, 18(4), 417-440. https://doi.org/10.1080/13540602.2012.696044.

Kelchtermans, G. (2017). 'Should I stay or should I go?': unpacking teacher attrition/retention as an educational issue. Teachers and Teaching, 1, 17. https://doi.org/10.1080/13540602.2017.13797 93.

Klassen, R. M., Durksen, T. L., Al Hashmi, W., Kim, L. E., Longden, K., Metsäpelto, R.-L., et al. (2018). National context and teacher characteristics: Exploring the critical non-cognitive attributes of novice teachers in four countries. Teaching and Teacher Education, 72, 64-74. https:// doi.org/10.1016/j.tate.2018.03.001.

Le Cornu, R. (2013). Building early career teacher resilience: The role of relationships. Australian Journal of Teacher Education, 38(4), 1-16. https://doi.org/10.14221/ajte.2013v38n4.4.

Mansfield, C. F., Beltman, S., Broadley, T., \& Weatherby-Fell, N. (2016a). Building resilience in teacher education: An evidenced informed framework. Teaching and Teacher Education, 54, 77-87. https://doi.org/10.1016/j.tate.2015.11.016.

Mansfield, C. F., Beltman, S., Weatherby-Fell, N., \& Broadley, T. (2016b). Classroom ready? Building resilience in teacher education. In R. Brandenberg, S. McDonough, J. Burke, \& S. White (Eds.), Teacher education: Innovation, intervention and impact (pp. 211-229). Singapore: Springer.

Mansfield, C. F., Ebersöhn, L., Beltman, S., \& Loots, T. (2018). Great southern lands: Making space for teacher resilience in South Africa and Australia. In M. Wosnitza, F. Peixoto, S. Beltman, \& C. F. Mansfield (Eds.), Resilience in education: Concepts, contexts and connections (pp. 53-71). Cham: Springer International Publishing.

Masten, A. S. (2014). Ordinary magic: Resilience in development. New York: The Guildford Press.

Papatraianou, L. H., \& Le Cornu, R. (2014). Problematising the role of personal and professional relationships in early career teacher resilience. Australian Journal of Teacher Education, 39(1), 100-116. https://doi.org/10.14221/ajte.2014v39n1.7.

Peixoto, F., Wosnitza, M., Pipa, J., Morgan, M., \& Cefai, C. (2018). A multidimensional view on preservice teacher resilience in Germany, Ireland, Malta and Portugal. In M. Wosnitza, F. Peixoto, S. Beltman, \& C. F. Mansfield (Eds.), Resilience in education: Concepts, contexts and connections (pp. 73-89). Cham: Springer International Publishing.

Schleicher, A. (2018). Valuing our teachers and raising their status: How communities can help, International Summit on the Teaching Profession. Paris: OECD Publishing. https://doi. org/10.1787/9789264292697-en.

Ungar, M. (2012). Social ecologies and their contribution to resilience. In M. Ungar (Ed.), The social ecology of resilience: A handbook of theory and practice (pp. 13-32). New York: Springer.

Wosnitza, M., Peixoto, F., Beltman, S., \& Mansfield, C. F. (Eds.). (2018). Resilience in education: Concepts, contexts and connections. Cham: Springer International Publishing.

Publisher's Note Springer Nature remains neutral with regard to jurisdictional claims in published maps and institutional affiliations.

Caroline Mansfield is Professor and Dean of the School of Education, University of Notre Dame Australia, Fremantle. Caroline's research primarily focuses on teacher resilience and wellbeing at a range of career stages and in diverse contexts. Caroline has led two successful projects in the field of teacher resilience (Keeping Cool and BRiTE) and in 2016 was awarded an Australian Learning and Teaching Fellowship. Her future work involves further investigation of the personal and contextual resources that 
enable teachers to maintain engagement, commitment and motivation, and thrive throughout their career.

Susan Beltman An Associate Professor at Curtin University, Susan Beltman researches in the area of resilience in various education settings. She has been a co-researcher on resilience-related Australian projects (Keeping Cool and BRiTE), a third country partner on the European project ENTREE, and chief investigator on an Australian National Centre for Student Equity in Higher Education funded project. She is current President and a Fellow of the Western Australian Institute for Educational Research (WAIER). 